\title{
KONSEP PEMBELAJARAN TUNTAS
}

\author{
Muh. Judrah \\ IAI Muhammadiyah Sinjai \\ muhjudrah68@gmail.com
}

\begin{abstract}
Abstrak
Tugas pendidik adalah menciptakan suasana pembelajaran yang dapat membuat peserta didik untuk senantiasa belajar dengan baik dan bersemangat. Suasana pembelajaran yang demikian akan berdampak positif dalam pencapaian hasil belajar yang optimal. Namun salah satu masalah besar dalam bidang pendidikan yang banyak diperbincangkan adalah rendahnya mutu pendidikan yang tercermin dari rendahnya rata-rata prestasi belajar. Masalah lain adalah guru lebih banyak menempatkan peserta didik sebagai objek dan bukan sebagai subjek didik. Dalam kegiatan pembelajaran guru harus melakukan perencanaan terlebih dahulu agar guru tersebut mampu mengajar peserta didiknya dengan baik. Pembelajaran tuntas merupakan strategi pembelajaran yang baik digunakan untuk meningkatkan mutu pendidikan, karena dengan pembelajaran tuntas, peserta didik dituntut untuk benar-benar menguasai materi yang dipelajari, dengan demikan maka peserta didik yang belum menguasai materi akan terus mengulang kembali materi yang telah dipelajarinya sampai dia benar-benar menguasainya, meskipun tidak $100 \%$ peserta didik tersebut memahaminya.
\end{abstract}

Kata Kunci:Konsep, Pembelajaran, Tuntas

\section{Pendahuluan}

Pendidikan di Sekolah dasar memiliki peranan yang sangat penting dalam pendidikan.Keberhasilan peserta didik di sekolah dasar sangat berpengaruh terhadap keberhasilannya di sekolah lanjutan. Oleh karena itu, pembelajaran di sekolah dasar merupakan suatu tantangan bagi seorang guru dalam keberhasilan peserta didiknya dimasa yang akan datang.

Tugas pendidik adalah menciptakan suasana pembelajaran yang dapat membuat peserta didik untuk senantiasa belajar dengan baik dan bersemangat. Suasana pembelajaran yang demikian akan berdampak positif dalam pencapaian hasil belajar yang optimal. Namun salah satu masalah besar dalam bidang pendidikan yang banyak diperbincangkan adalah rendahnya mutu pendidikan yang tercermin dari rendahnya rata-rata prestasi belajar. Masalah lain adalah guru lebih banyak menempatkan peserta didik sebagai objek dan bukan sebagai subjek didik.

Kebanyakan guru di sekolah dasar hanya menyampaikan materi saja (ceramah) kemudian dilanjutkan pemberian tugas tanpa mengetahui apakah para peserta didiknya sudah menguasai materi yang sudah disampaikan. Padahal dalam hal ini penguasaan materi pembelajaran secara tuntas adalah hal yang paling penting demi tercapainya tujuan pembelajaran. Akibatnya, banyak peserta didik yang tidak menguasai materi pembelajaran meskipun sudah dinyatakan tamat dari sekolah. Jadi tidak salah kalau mutu pendidikan di sekolah masih rendah.

\section{Metode}

Penelitian ini menggunakan metode penelitian deskriptif kualitatif untuk menjelaskan mengenai konsep belajar tuntas untuk anak-anak. 


\subsection{Prinsip Pembelajaran Tuntas}

Belajar tuntas (mastery learning) adalah pencapaian taraf penguasaan minimal yang ditetapkan untuk setiap unit bahan pelajaran baik secara perseorangan maupun kelompok, dengan kata lain apa yang dipelajari peserta didik dapat dikuasai sepenuhnya (Moh. User, 1993: 96).

Ide teoritis inti dalam mastery learning didasarkan pada persektif yang menarik dari john B. Carroll tentang makna bakat. Carroll memandang bakat sebagai jumlah waktu yang akan membawa seseorang untuk mempelajari suatu materi yang diberikan, bukan sebagai kapasitas seseorang itu untuk menguasainya (Wahyudin, 2008: 28) Dengan pemberian waktu yang cukup sesuai dengan kemampuan peserta didik diharapkan penguasaan penuh dalam pembelajaran dapat tercapai.

Apabila pembelajaran tuntas dilakukan dalam kondisi yang tepat maka semua peserta didik mampu belajar dengan baik dan memperoleh hasil yang maksimal terhadap seluruh materi yang dipelajari. Agar semua peserta didik memperoleh hasil yang maksimal, pembelajaran tuntas harus dilakukan dengan sistematis. Supaya pembelajaran terstruktur Winkel menyarankan sebagai berikut:

1. Tujuan-tujuan pembelajaran yang harus dicapai ditetapkan secara tegas. Semua tujuan dirangkaikan dan materi pelajaran dibagi-bagi atas unit-unit pelajaran yang diurutkan, sesuai dengan rangkaian semua tujuan pembelajaran.

2. Peserta didik dituntut supaya mencapai tujuan pembelajaran lebih dahulu, sebelum peserta didik diperbolehkan mempelajari unit pelajaran yang baru untuk mencapai tujuan pembelajaran. Jadi peserta didik dilarang untuk mempelajari pokok bahasan berikutnya sebelum peserta didik tersebut mamahami pokok bahasan sebelumnya.

3. Ditingkatkan motifasi belajar peserta didik dan efektivitas usaha belajar peserta didik, dengan memonitor proses belajar peserta didik melalui testing berkala dan kontinyu, serta memberikan umpan balik kepada peserta didik mengenai keberhasilan atau kegagalannya pada saat itu juga.

4. Memberikan bantuan atau pertolongan kepada peserta didik yang masih mengalami kesulitan (Winkel, 1996: 413).

Strategi pembelajaran tuntas dapat diterapkan secara tuntas untuk meningkatkan kualitas pendidikan. Benyamin. S. Bloom menyebutkan 3 strategi dalam belajar tuntas yaitu mengidentifikasi prakondisi, mengembangkan prosedur operasional dan hasil belajar. Selanjutnya mengimplementasikan dalam pembelajaran kalsikal dengan memberikan "bumbu" untuk menyesuaikan dengan kemampuan individual, yang meliputi:

1. Corrective Technique. Pengajaran remedial, yang dilakukan dengan memberikan pengajaran terhadap tujuan yang gagal dicapai oleh peserta didik, dengan prosedur dan metode yang berbeda dari sebelumnya.

2. Memberikan tambahan waktu kepada peserta didik yang membutuhkan (belum menguasai bahan secara tuntas) (Yamin, 2006: 121-122)

Prinsip-prinsip dasar belajar tuntas adalah:

1. Bakat

Setiap guru hendaknya menyadari bahwa bakat setiap individu peserta didik berbeda satu dengan yang lainnya. Demikian pula dalam kemampuan untuk menangkap pelajaran dan tingkat usahanya bervariasi (Hamadi, 2005: 157).

2. Mutu pengajaran

Mutu pengajaran ini berkaitan dengan cara seorang guru menyampaikan materinya sehingga pelajaran itu berhasil dan berkualitas.

3. Kemampuan memahami pengajaran

Kemampuan untuk memahami pengajaran menggambarkan kemampuan peserta didik untuk memperoleh manfaat dari pengajaran itu dan erat kaitannya dengan kecerdasannya secara umum. Model ini memandang bahwa kualitas pengajaran dan kemampuan peserta didik untuk memahami pengajaran itu berinteraksi untuk mempengaruhi jumlah waktu yang dibutuhkannya untuk menguasai tugas secara tuntas sesuai dengan aptitude-nya. Jika kualitas pengajarannya dan kemampuannya untuk 
memahami itu tinggi, maka dia hanya akan membutuhkan sedikit waktu tambahan atau tidak sama sekali. Sebaliknya, jika kedua faktor tersebut rendah, maka dia akan membutuhkan banyak waktu tambahan.

\section{Ketekunan}

Siswa yang tekun mengulang kembali pelajaran akan menjadikan siswa cepat memahami sehingga pembelajaran yang dilakukan akan berhasil.

5. Waktu

Faktor waktu dipergunakan sebagai satu variabel dalam mengindividualisasikan pembelajaran dan dengan demikian dapat menghasilkan ketuntasan belajar peserta didik. Dalam Winnetka Plan, kecepatan kegiatan belajar peserta didik ditentukan oleh peserta didik sendiri. Masing-masing peserta didik diberi waktu sesuai dengan kebutuhannya untuk menuntaskan satu unit. Dalam metode Morrison, masing-masing peserta didik diberi waktu belajar sesuai dengan tuntutan guru hingga semua atau hampir semua peserta didik menuntaskan unit itu (Block, 1971: 4).

Ciri-ciri pembelajaran dengan prinsip Pembelajara tuntas adalah sebagai berikut:

1. Pengajaran didasarkan atas tujuan-tujuan pendidikan yang telah ditentukan terlebih dahulu. Tujuan dari strategi belajar mengajar adalah hampir semua peserta didik/ semua peserta didik dapat mencapai tingkat penguasaan tujuan pendidikan.

2. Memperhatikan perbedaan individu. Yang dimaksud perbedaan di sini adalah perbedaan peserta didik dalam hal menerima rangsangan dari luar dan dari dalam dirinya serta laju belajarnya.

3. Evaluasi yang dilakukan secara kontinyu dan didasarkan atas kriteria. Evaluasi dilakukan secara kontinyu sangat penting dilakukan agar guru dapat menerima umpan balik yang cepat, sering dan sistematis.

4. Menggunakan program perbaikan dan program pengayaan. Program perbaikan dan pengayaan adalah sebagai akibat dari penggunaan evaluasi yang kontinyu dan berdasarkan kriteria serta pandangan terhadap perbedaan kecepatan belajar mengajar peserta didik dan administrasi sekolah.

5. Menggunakan prinsip peserta didik belajar aktif. Prinsip peserta didik belajar aktif memungkinkan peserta didik mendapatkan pengetahuan berdasarkan kegiatan-kegiatan yang dilakukannya sendiri.

6. Menggunakan satuan pelajaran yang kecil. Cara belajar mengajar dengan menggunakan prinsif belajar tuntas menuntut pembagian bahan pengajaran menjadi unit yang kecil-kecil (Subroto, 1996: 102).

Peserta didik yang berbakat tinggi memerlukan waktu yang relatif sedikit untuk mencapai taraf penguasaan bahan dibandingkan dengan peserta didik yang memiliki bakat rendah. Peserta didik dapat mencapai penguasaan penuh terhadap bahan yang disajikan. Bila kualitas pengajaran dan kesempatan waktu belajar dibuat tepat sesuai dengan kebutuhan masing-masing peserta didik (Yamin, 2008: 216).

Perilaku intelektual, aspek teoritis dan tingkat abstraksi mereka menunjukkan karakteristik mental yang berbeda dalam kecepatan melihat hubungan yang bermakna, tanggap mengaitkan sosiologis, mudah mengadaptasikan prinsip abstrak kesituasi konkret dengan mengkaji komponen situasi yang identik, serta mampu menggeneralisasikan (Semiawan, 1997: 113).

Seorang peserta didik tidak mencapai tingkat keberhasilan yang dituju, hal ini tidak disediakan jumlah waktu yang cukup, sesuai dengan kebutuhan peserta didik atau karena waktu yang disediakan dan sebenarnya cukup itu tidak digunakan dengan sungguh-sungguh. Dengan demikian, tingkat penguasaan dalam belajar bergantung dengan jumlah waktu yang disediakan, misalnya bila seseorang hanya belajar dengan sungguh-sungguh selama 2 jam, padahal disediakan jumlah waktu 3 jam, maka tingkat penguasaan atau tingkat keberhasilan hanya mencapai $67 \%$ dari target yang direncanakan. Waktu yang disediakan untuk belajar, selain bergantung pada kecepatan belajar peserta didik, juga ikut ditentukan oleh kualitas pengajaran dan kemahiran peserta didik untuk menangkap suatu uraian dalam bentuk lisan dan tertulis (Winkel, 1996: 414). 
Pada dasarnya belajar tuntas (mastery learning) akan menciptakan peserta didik memiliki kemampuan dan mengembangkan potensi yang dimilikinya, mengecilkan perbedaan antara anak cerdas dengan anak yang tidak cerdas. Belajar tuntas (mastery learning) menciptakan peserta didik dapat mencapai tujuan pembelajaran, sehingga di dalam kelas tidak terjadi anak cerdas akan mencapai semua tujuan pembelajaran, sedangkan peserta didik yang kurang cerdas mencapai sebagian tujuan pembelajaran atau tidak mencapai sama sekali tujuan pembelajaran.

\subsection{Pelaksanaan Pembelajaran Tuntas}

Setelah guru melakukan proses perencanaan maka tahap selanjutnya yaitu proses pelaksanaan

belajar tuntas. Pelaksanaan belajar tuntas terdiri atas langkah-langkah sebagai berikut:

1. Kegiatan orientasi. Kegiatan ini mengorientasi peserta didik terhadap strategi belajar tuntas yang berkenaan dengan orientasi tentang apa yang akan dipelajari oleh peserta didik dalam jangka satu semester dan cara belajar yang harus dilakukan oleh peserta didik. Dalam hal ini guru menjelaskan keseluruhan bahan yang telah direncanakan dalam tabel spesifikasi, lalu dilanjutkan dengan prates yang isinya sama dengan isi tes sumatif.

2. Kegiatan belajar mengajar. Dalam kegiatan belajar mengajar ini yang harus dilakukan oleh seorang guru yaitu :

a) Guru memperkenalkan TIK pada satuan pelajaran yang akan dipelajari dengan cara memperkenalkan tabel spesifikasi tentang arti dan cara mempergunakannya untuk kepentingan bimbingan belajar atau menunjukkan topik umum atau konsep umum yang akan dipelajari.

b) Penyajian rencana kegiatan belajar mengajar beardasarkan standar kelompok. Dengan cara ini para peserta didik akan terhindar dari kebingungan dan menumbuhkan gagasan tentang strategi belajar yang perlu dilakukan sendiri.

c) Penyajian pelajaran dalam situasi kelompok berdasarkan satuan pelajaran.

d) Melaksanakan diagnostic progress test.

e) Mengidentifikasi kemampuan belajar peserta didik yang telah memuaskan dan yang belum memuaskan.

f) Menetapkan peserta didik yang hasil belajarnya telah memuaskan.

g) Memberikan kegiatan korektif kepada peserta didik yang hasil belajarnya "belum memuaskan". Ada tiga teknik yang dapat dikembangkan yaitu: bantuan tutor teman sekelas, guru mengajarkan kembali bahan yang berhubungan dengan pokok ujian apabila sebagian besar peserta didik belum memuaskan. Peserta didik yang bersangkutan memilih sendiri daftar korektif yang telah disediakan dan melakukannya secara individual.

h) Memonitor keefektifan kegiatan korektif.

i) Menentapkan kembali peserta didik yang hasil belajarnya memuaskan.

3. Menentukan tingkat penguasaan bahan. Setelah pelajaran selesai dilakukan maka guru melakukan tes untuk mengetahui sejauh mana kemampuan peserta didik.

4. Memberikan atau melaporkan kembali tingkat penguasaan setiap peserta didik. Kegiatan ini bertujuan agar mengetahui tingkat penguasaan setiap peserta didik. Mereka diberi tabel spesifikasi, bahan yang sudah dikuasai diberi tanda $M$ (mastery) sedangkan yang belum diberi tanda NM ( non mastery).

5. Pengecekan keefektifan keseluruhan program. Keefektifan strategi belajar tuntas ditandai berdasarkan hasil yang dicapai oleh peserta didik. Untuk itu ada dua cara yang dapat ditempuh oleh guru: (1) membandingkan hasil yang dicapai oleh kelas yang menggunakan strategi belajar tuntas dengan kelas yang menggunakan strategi lain. (2) terlebih dahulu membuat hipotesis tentang hasil belajar jika menggunakan strategi belajar tuntas lalu dibuktikan berdasarkan hasil belajar kelas senyatanya. Dengan cara demikian maka dapat diketahui keefektifan keseluruhan program yang telah dilaksanakan (Winkel, 1996: 93). 
Seperti halnya dengan strategi pembelajaran yang lain, pembelajaran tuntas juga memiliki kebaikan dan kelemahan diantaranya yaitu:

1. Kebaikan Belajar Tuntas

a) Strategi ini sejalan dengan pandangan psikologi belajar modern yang berpegang pada prinsip perbedaan individual dan belajar kelompok.

b) Strategi ini memungkinkan peserta didik belajar lebih aktif sebagaimana disarankan dalam konsep CBSA yang memberi kesempatan kepada peserta didik untuk mengembangkan diri sendiri, memecahkan masalah sendiri dengan menemukan dan bekerja sendiri.

c) Dalam strategi ini guru dan peserta didik diminta bekerja sama secara partisipatif dan persuasif, baik dalam proses belajar maupun dalam proses bimbingan terhadap peserta didik lainnya.

d) Strategi ini berorientasi kepada peningkatan produktifitas hasil belajar.

e) Penilaian yang dilakukan terhadap kemajuan belajar peserta didik mengandung unsur objektivitas yang tinggi.

2. Kelemahan Belajar Tuntas

a) Para guru umumnya masih mengalami kesulitan dalam membuat perencanaan belajar tuntas karena harus dibuat untuk jangka satu semester, disamping penyusunan satuan-satuan pelajaran yang lengkap dan menyeluruh.

b) Strategi ini sulit dalam pelaksanaannya karena melibatkan berbagai kegiatan, yang berarti menuntut macam-macam kemampuan yang memadai.

c) Guru-guru yang sudah terbiasa dengan cara-cara lama akan mengalami hambatan untuk menyelenggarakan strategi ini yang relatif lebih sulit dan masih baru.

d) Strategi ini membutuhkan berbagai fasilitas, perlengkapan, alat, dana. dan waktu yang cukup besar.

e) Untuk melaksanakan strategi ini mengacu kepada penguasaan materi belajar secara tuntas sehingga menuntut para guru agar menguasai materi tersebut secara lebih luas, menyeluruh, dan lebih lengkap. Sehingga para guru harus lebih banyak menggunakan sumber-sumber yang lebih luas (Hamalik, 2001: 86).

\section{Simpulan.}

Pembelajaran tuntas adalah suatu strategi pembelajaran yang diindividualisasikan dengan menggunakan pendekatan kelompok. Pembelajaran tuntas diharapkan mampu mengatasi kelemahan yang terdapat pada strategi pembelajaran lainnya.

Dalam kegiatan pembelajaran guru harus melakukan perencanaan terlebih dahulu agar guru tersebut mampu mengajar peserta didiknya dengan baik. Pembelajaran tuntas merupakan strategi pembelajaran yang baik digunakan untuk meningkatkan mutu pendidikan, karena dengan pembelajaran tuntas, peserta didik dituntut untuk benar-benar menguasai materi yang dipelajari, dengan demikan maka peserta didik yang belum menguasai materi akan terus mengulang kembali materi yang telah dipelajarinya sampai dia benar-benar menguasainya, meskipun tidak $100 \%$ peserta didik tersebut memahaminya.

Dalam strategi ini menuntut peserta didik untuk aktif dalam kegiatan pembelajaran, selain itu penilaian dalam pembelajaran tuntas ini mengandung unsur objektifitas yang tinggi.

\section{Daftar Pustaka}

Ahmadi, Abu. Strategi Belajar Mengajar. Bandung: CV Pustaka Setia, 2005.

Block, James. Introduction to Mastery Learning: Theory and Practice. New York: Holt, Rinehart and Winston Inc. 1971. 
Hamalik, Oemar. Pendekatan Baru Strategi Belajar Mengajar Berdasarkan CBSA. Bandung: Sinar Baru. 2001.

Semiawan, Conny R.Persfektif Pendidikan Anak Berbakat.Jakarta:Gramedia Widiasarana, 1997.

Subroto, Suryo. Proses Belajar Mengajar di Sekolah. Jakarta: Rineka Cipta, 1996.

User, Usman Moh.dan Lilis Setiawati. Upaya Optimalisasi Kegiatan Belajar Mengajar. Bandung: Remaja Rosdakarya, 1993.

Wahyudin.Pembelajaran dan Model-model Pembelajaran Seri 3.Jakarta: CV. IPA Abong. 2008.

Winkel, WS.Psikologi Belajar. Jakarta: Gramedia Widia Sarana Indonesia, 1996.

Yamin, Martinis. Paradigma Pendidikan Kontruktivistik"Implementasi KTSP \& UU No.14 Tahun 2005 tentang Guru dan Dosen”. Jakarta:Gaung Persada Press, 2008.

Yamin, Martinis. Profesionalisasi Guru dan Implementasi Kurikulum Berbasis Kompetensi. Jakarta: Gaung Persada Press, 2006. 